\title{
Brazilian court disrespect patient autonomy
}

\begin{abstract}
Background: the autonomy of the patient to decide on his own destiny is still a subject little faced and little understood by the Brazilian courts.
\end{abstract}

Objective: the present essay aims to present a case report in which a Brazilian court, while acknowledging the patient's civil capacity, forced him to undergo hemodialysis treatment, arguing that his decision was not reflected.

Method: it is a case report reported in the Brazilian media and whose analysis was carried out based on bibliographical research.

Results: the study demonstrates a strong tendency of the Brazilian courts to intervene in clinical decisions of chronic patients.

Conclusion: state intervention by determining that civilly capable people undergo therapies they do not want is a serious violation of the dignity of the human person.

Keywords: hemodialysis, self-determination, autonomy of the patient, intervention
Volume 2 Issue I - 2018

\author{
Fernanda Schaefer Rivabem \\ Department of Law of Social Relations, Federal University of \\ Paraná, Spain
}

Correspondence: Fernanda Schaefer Rivabem, Arcésio Correia Lima St., 4 I I, Atuba, Curitiba-Paraná-Brazil, Postal Code 82.630-130, UniCuritiba, Tel +55(4I)99669-6107, +55(4I)35986107, Email ferschaefer@hotmail.com

Received: December 02, 2017 | Published: January 25, 2018

\section{Introduction}

On November 28, 2017 a judge of the $2^{\text {nd }}$ Civil Court of Trindade (GO-Brazil) has ordered the interdiction for two years of a twenty too year old man, a chronic renal patient, who refuses to continue hemodialysis treatment. The judge, confirming an injunction granted in February of the same year, named the boy's mother as his healer, and determined that she would take the necessary steps to comply with the medical prescriptions, forcing the boy to undergo psychotherapeutic follow-up and could not be used no form of physical coercion or sedation for the enforcement of the judicial order. ${ }^{1}$

Even after being heard by the judge and claiming to be fully aware of his condition and the consequences of failing to perform the treatment, explaining that this does not represent real chances of cure, characterizing as a "arduous and painful process", the magistrate denied the right to not undergo hemodialysis. The judge said that the young man made the decision "without reflection and with little emotional investment, preventing him from capturing and processing situations in the complexity required". ${ }^{2} \mathrm{He}$ further stated that "although cognitive development and patient awareness are not compromised, it does not have the necessary exemption to corroborate an effectively free will" because there are psychological and psychiatric elements that affect his understanding capacity.

The judge in fact, disregarded that the decision is reflected since 2015, when the patient discovered the disease. In June of 2015, while still living in the United States with his father, the boy was diagnosed with kidney failure and was included in the transplant list. ${ }^{3}$ In the same month, refusing to undergo transplantation, he returned to Brazil to live with his mother, initiating hemodialysis treatment. After a few sessions, considering the pains of the disease and a treatment that only prolongs his life and does not bring him chances of cure, the boy (capable according to the Brazilian laws) after being duly clarified by his doctors, consciously chose to abandon therapy.

\section{Discussion}

The decision is supported by Art. 13, of the Civil Code, which guarantees the right to own body and Art. 15, of the Civil Code, which expressly allows the refusal of medical treatment. However, although there is legal provision, the State demonstrates a clear willingness to intervene and limit the patient autonomy over his own body considering this right of personality absolutely unavailable.,5 And it is this interpretation that conflicts head-on with the constitutional principle of the dignity of the human person (art. 1o., III, CF) and with the rule that no one is obliged to do or not to do anything other than by virtue of law (art. 5o., II, CF).

There is, in fact, in Brazil a historical, scientific and cultural obsession with the control of the body that results from the attempts to control human subjectivity itself, a result of Biopower that constantly acts in the bodies: controlling, marking, directing, stimulating, training and limiting them. The dignity of the patient, his selfdetermination, is disregarded in the name of an unrestricted obligation to treat when treatment is available. In fact, the physical body can no longer be thought dissociated from the psychological or social environment in which it is inserted. In this way, the human body (as an element of personality) must be thought from a post-metaphysical concept of person, that is, as an element that conforms the personal identity and the instrument that makes the identity itself. This premise is important to understand the scope of the right to own body, since self-determination (as ability to make choices and take responsibility for them) should be thought from the constitutive values of one's own personality and the way these values interact with the body and autonomy for self-realization. ${ }^{6}$

When talking about voluntary limitations to personality rights, it is necessary to understand that the right holder is not renouncing the right to legal ownership, but is renouncing his or her exercise, without affecting the ability to enjoy the assets of the personality (unavailable by essence), but rather affecting aspects or characteristics of these goods, on which a certain freedom (availability) can be admitted. ${ }^{7,8}$ The person acts with the intention of reducing the exercise of rights and not with the intention of stripping them completely and, therefore, the voluntary limitations of the right to own body presupposes a necessary disposition of some projections of the own personality.

Autonomy is undoubtedly a guarantor and promoter of personality (here considered in its objective aspect as a set of attributes of the 
human person). Recognizing the subjectivity of man is the first step in understanding the need to guarantee and protect the will and selfdetermination of it, and this is only possible by breaking the state paternalism reflected in art. 13, of the Civil Code and casting new glances on the limitations contained in this provision, since in subjective existential situations the legislator or the judge should not condition the forms of behavior because they do not know the existential needs of each one.

\section{Conclusion}

Thinking about voluntary limitations to personality rights presupposes the autonomy of the right holder over the body itself, autonomy that can result from the subject acting on his own body (self-harm) or from allowing others to act on him (consented lesion), both resulting from a reflected process on personal choices, since, once again, cannot start from the idea that there is an ideal model of behavior. Removing the patient's autonomy from the body on the basis of reestablished ethical and social models leads to the degradation of the right holder himself who, by personal choices or for clinical reasons, cannot adapt to these standards. To deny the patient the right not to undergo clinical treatment, conscious of the consequences of his decision, is to deny him his own human dignity.

\section{Acknowledgements}

None.

\section{Conflict of interest}

The author declares no conflict of interest

\section{References}

1. Cortiano junior eroulths. Alguns apontamento sobre os chamados direitos de personalidade. In: Fachin Luiz Edson editors. Repensando fundamentos do direito civil brasileiro contemporâneo. Renovar, Rio de Janeiro, Brazil: Springer; 2000. p. 31-56.

2. Gediel José Antônio Peres, Pinheiro Rosalice Fidalgo. Dos códigos às constituições: os direitos fundamentais de personalidade. In: conrado marcelo \& pinheiro rosalice editors. Direito privado e constituição. Curitiba, Brazil: Juruá; 2009. p. 61-85.

3. Godinho adriano marteleto. Direito ao próprio corpo. Curitiba, Brazil: Juruá; 2015.

4. Lara Mariana. O direito à liberdade de uso e (auto) manipulação do corpo. Belo Horizonte: D’Plácido; 2014.

5. Otero Paulo. Disponibilidade do próprio corpo e dignidade da pessoa humana. In: Cordeiro António Menezes editors. Estudos em honra do Professor Doutor José de Oliveira Ascensão. Almedina, Coimbra, Portugal: Springer; 2008. p. 107-138.

6. Teixeira ana carolina brochado. Saúde, corpo e autonomia privada. Renovar, Rio de Janeiro, Brazil: Springer; 2010.

7. Tomazela José Maria. Justiça determina interdição de jovem que recusa hemodiálise para morrer em Goiânia; 2007.

8. Schaefer fernanda. Amputees by choice e autonomia sobre o próprio corpo. In: Maria de Fátima Freire, et al. editors. Novos direitos privados. Arraes, Belo Horizonte/São Paulo, Brazil: Springer; 2016. 